\title{
A review on the diversity of Melon
}

\author{
M Lija* \& S Suhara Beevy \\ Department of Botany, University of Kerala, Kariavattom 695 581, India \\ *Email: lijaomana@gmail.com
}

\section{ARTICLE HISTORY}

Received: 07 June 2021

Accepted: 17 September 2021

Available online: 14 November 2021

\section{KEYWORDS}

genetic diversity

homologous

melon

varieties

\section{ABSTRACT}

The species Cucumis melo L. (Melon) is a polymorphic taxon encompassing many botanical and horticultural varieties. Melon fruits exhibit substantial variability in their form, shape, skin characters, flesh color, flesh thickness, sweetness, seed cavity, seed size etc., which reflects in the market value of melon. This existing diversity in melon germplasm leads botanists to propose different classifications at the specific and infraspecific levels. The majority of classifications are based on morphological and molecular characteristics. Morphologic traits such as flower and fruit characteristics (sex expression, fruit size and shape, fruit skin color, $\mathrm{pH}$, flesh color, taste, aroma, sugar composition, seed size and shape) were used in the past centuries for melon diversity analysis. Later on, scientists correlate these phenotypic and biochemical traits ( $\mathrm{pH}$, Total Soluble Solids, Ascorbic acid content, Titratable acidity) with genotypic variability by molecular tools. Molecular tools generally used for melon diversity analysis are RAPD, RFLP, AFLP, SSR markers and Single Nucleotide Polymorphism (SNP). This article emphasizes the progress of studies in the species Cucumis melo L. and its varieties since 1753. Particular attention has been paid to collect data regarding different horticultural groups of the species, and a recent infraspecific classification of the species has also been outlined. Even though the modern molecular techniques provide new insight to melon classification still there is an existing disparity in these classifications, which could be visible to the scientific world.

\section{Introduction}

Cucumis melo L., commonly known as melon, is a tropical plant species that belongs to the family Cucurbitaceae. According to FAO 2019 (1), the world production of melon is 32 million t from 1.14 million ha of land. It was 8.8, 13.5, 19.8, 27.3 million t in 1980, 1990, 2000 and 2011 respectively and major melonproducing countries are China (17.1 million tons), followed by Turkey, Iran, Egypt and India (2). The genus Cucumis consists of 52 species with two geographical centers of origin, such as Asia and Africa and it is a diploid crop with $2 \mathrm{n}=2 \mathrm{x}=24$ chromosomes, showing considerable variation in fruit sizes and shapes (3-5).

\section{Systematic Position of Cucumis melo $\mathrm{L}$.}

Kingdom - Plantae

Phylum - Magnoliophyta

Class - Angiospermae

Category - Fabrids

Order - Cucurbitales

Family - Cucurbitaceae

\section{Genus - Cucumis}

\section{Species - Cucumis melo*}

\section{*APG 1V System of Classification.}

The plant is a softly hairy annual. Vines are monoecious or andro-monoecious, 1.20-3.50m long. Root system large and superficial. The stem is densely pubescent, ridged, or striate. Leaves are orbicular or ovate to reniform, triangular or pentagonate, shallowly 3-5 lobed; leaf 8-12 cm long with midrib length of $8 \mathrm{~cm}$ or greater; margin undulating-wavy; petiole 4-10 cm long; tendrils simple. Flowers are bright yellow; female flowers $3.5 \times 2.6 \mathrm{~cm}$, solitary, male flowers $4.6 \times 2.2 \mathrm{~cm}$, in $4-5$ per axil; calyx 5lobed, 6-8 mm long; sepals ficiform, subulate or leafshaped, covered with dense, long hairs; corolla deeply 5-partite, petals round, $2 \mathrm{~cm}$ long; stamens 3, free, connectives of anthers prolonged; pistil with 3-5 placentas and stigmas. Fruits normally cylindric-oval with faded markings or green, mature fruit weight $2.25-4 \mathrm{~kg}$, size $36-62 \times 16-24 \mathrm{~cm}$, flesh usually yellowpeach-pink, strong external and internal musky aroma, blunt at the distal end; seed creamish-yellow $0.9-1.090 .3-0.4 \mathrm{~cm}$.

(C) Lija \& Beevy (2021). This is an open-access article distributed under the terms of the Creative Commons Attribution License, which permits unrestricted use, distribution and reproduction in any medium, provided the original author and source are credited (https://creativecommons.org/licenses/by/4.0/). 
Botanically fruits of both melons and cucumber are described as fleshy berries, but they have been harvested at different physiological stages such that in cucumbers, fruits are an unripe berry, whereas, in melons, these are ripe berries $(8,9)$. Matured melon fruits detach from the plant naturally by making an abscission layer on the stem. The cultivated varieties of melon include both sweet and non-sweet "dessert" forms. The non-dessert forms (e.g., culinary melon, oriental pickling melon etc.) are consumed as raw, pickled, or cooked (10), but sweet dessert (e.g., snap melon, musk melon etc.) forms can be used in various dessert preparation.

\section{Nutritional Value of melon}

Melons carry a vast amount of photochemicals which are capable to fight against human diseases. Almost all cucurbit fruits are significant source of vitamin C, Provitamin A, toxic folic acid, phenolic phytochemicals, dietary fibers, minerals, cucurbitacin. Among these chemicals such as cucurbitacin, lithium and zinc helps in cancer prevention, fighting depression, prevention of ulcers and removal of dandruff, stimulating immune system (11-13). In commercial cultivars, the cucurbitacin level is negligible. However, the pharmacological and ethno botanical properties of melons are due to cucurbitacin (14). In addition to this, high dietary fibre in melon make it an ideal choice to avoid dehydration. As per the studies conducted by Food and Drug Administration, USA on Musk melon and Honey dew melons, the varieties were not only good source of Potassium and Vitamin $\mathrm{C}$ but also low with Fat, Sodium and calories. They also reported that among the two varieties, musk melon is an excellent source of Provitamin A or beta Carotene (13).

\section{Historical background on melon cultivation}

Linn' in 1753 termed the genus name 'Cucumis' and described five species of cultivated melons in Species Plantarum (15). Miller coined the word 'Melo,' but he neither described any species nor transferred any species $(16,17)$. Later in 1859, Naudin united all these five species into a single species, Cucumis melo and its cultivated varieties as var. acidulous (18). Later, a simplified version of Naudin's taxonomy into a single wild variety, Cucumis melo var. agrestis, six cultivated ones, momordica, cantalupensis, flexuous, indorous, conomon and dudain (19, 20). Again there are classification on east and west melons into five varieties momordica, acidulous, conomon, makuwa and chinensis, all of which belong to the subspecies $C$. melo ssp agrestis $(21,22)$.

Based on archaeological records (seeds), illustrations, and analysis of the available text, it could be predicted that melon cultivation has been started in China 3000 year BC, in India in 2000 BC and in Egypt 1500 BC (23-29). India has a long history of melon cultivation and is considered a secondary centre of genetic diversity of cultivated melon. In India, Mughal rulers introduced cultivated melon from Central Asia (30). Columbus introduced melon to the new world on his first travel which was looking like watermelon. Later, Americans adopted this crop and started cultivation (31).
The most ancient records on cultivated melon appeared in Egyptian mural paintings (32). Pangalo studied a live collection of 3000 specimens of melons and proposed a multilevel taxonomy based on homologous series $(22,33)$. Then he subdivided four $C$. melo varieties in the homologous series into two homologous subspecioides, cultus or cultivated types and agrestis or wild types, and each subspeciode again divided into "types." He also reported that sweet melons were not known in the Roman period and were imported from Persia or Caucus by travellers (15).

The pattern of melon evolution and divergence is still a question to the scientific world. Melon is of African origin, but the centre of diversity is from Turkey to Japan (34). A distributional map of important melon cultivation areas are given in the Fig 1. Cytological studies of melon germplasm based on low chromatin content, two nucleolar organizer, low chiasma frequency shown that non dessert melons are more primitive than dessert forms. But species like $C$. hystrix chakr. $(2 \mathrm{n}=24)$ is native to Asia $(35,36)$ and it's morphological and biochemical characters similar to $C$. sativus and its chromosome number is equal to $C$. melo. This evidence indicates that $C$. hystrix is a possible bridge between these two species (37). C. melo was considered the most developed ancient cultivated species among the three species and through many changes, it would evolve into the existing elite forms $(11,23,38,39)$.

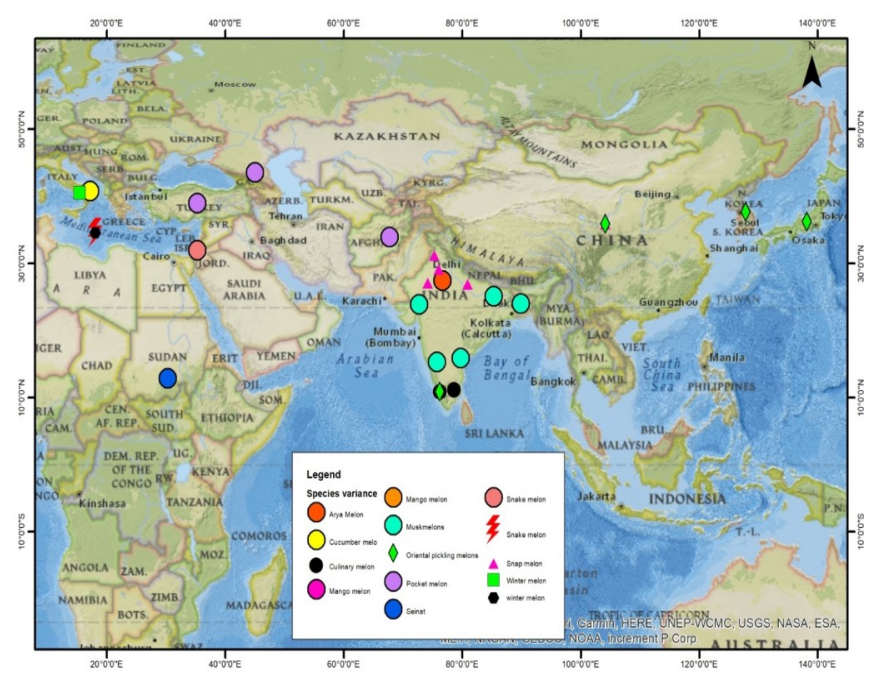

Fig. 1. A world distributional map of major melon growing area.

\section{Molecular diversity studies on melon}

The phylogenetic relationship between various groups of cultivated melon and its genetic diversity was studied by analysis of morphological characters (40, 41), cytological characters (42) and molecular polymorphism by DNA markers. DNA markers such as isozymes (41, 43), restriction fragment length polymorphisms (RFLPs) (44), random amplified polymorphic DNA (RAPD) (15, 45-49), simple sequence repeats or microsatellites(SSR) $(45,50,51,53,55,56)$, Amplified fragment length polymorphism (AFLP) (53) and SNP (Single Nucleotide polymorphism) by genotyping by sequencing $(54,55)$ etc have been extensively used to measure genetic diversity in 
melon germplasm. There had been conducted a comprehensive study on 54 wild and cultivated melon types using RAPD and inter-SSR markers which leads to the identification of the two melon subspecies, melo and agrestis, as proposed (56). These reports show a clear-cut genetic demarcation between subsp. agrestis and subsp. melo and it was defined by $(19,21,57)$. It was analyzed AFLP of ninety-nine accessions of melon (Cucumis melo L.) from East and South Asia revealed its genetic relationship between East and South Asian melon (53). However, SSR markers have been used in a relatively limited narrow array of melon germplasm. The genetic variability studies performed with SSR markers in 27 accessions of melon pointed out their genetic relationships which could be further investigated for their classification and origin (51). The genotyping-by-sequencing (GBS) is considered as a simplest approach to discover SNPs in highly diverse crop species (58). Based on this, assessed 143 melon accessions of 15 horticultural groups in two subspecies, subsp. melo and subsp. agrestis (54). Recently, 164 genome-wide SNP markers were analyzed in the Oriental melon which leads to differentiate the varieties into ten clear groups. This result shows that SNP markers with high validation rate and marker-trait associations serve as a useful tool for varietal identification, genetic diversity studies (55).

Melon (Cucumis melo L.), one major cucurbit throughout the world, has intense diversification and significant physiological, molecular and morphological variations from its cultivar sub-group level $(15,18,19)$. Various infraspecific classifications have been proposed on the crop based on these variations. One of the important morphological characters which would consider for the classification of this species is ovary hairiness and based on this, they have divided the species into two subspecies, such as $C$. melo ssp. melo and $C$. melo ssp. agrestis (40, $56,57)$. Further, this subspecies were classified into 16 taxonomic groups or varieties, which leads to a quadrinomial nomenclature (eg: $C$. melo ssp. agrestis var. momordica) (21) and as per this classification, $C$. melo ssp. agrestis includes five melon types (groups of cultivars) momordica Roxb. (snap melon), acidulus Naudin, conomon Thunb., makuwa Makino and chinensis Pangalo (pickling melons) and (distributed in India to the Far East); $C$. melo ssp. melo comprises 11 types cantalupensis Naudin, reticulatus Ser. (cantaloupe, muskmelon), flexuosus L. (snake melon), inodorus H.Jac. (Winter melon or Casaba melon), chandalak Gabaev, adana Pangalo, ameri Pangalo (Asian melons), chate Hasselq. (Cucumber melon), chito Morren (Mango melon), dudaim L. (Pocket melon) and tibish Mohamed (distributed in Central, Western India, Africa, Europe, Western Asia and America) (58). Later, this scheme was adapted to the International Code for Cultivated Plants with five groups in ssp. agrestis and eleven groups in ssp. melo (60-64). Nevertheless, in the earlier studies, Wild melons have been included in a separate tribe referred to as 'agrestis' (18). However, morphological and molecular analyses pointed out that the wild types show resemblances with the paraphyletic agrestis and melo subspecies sensu Kirkbride (64). A schematic

\section{Schematic Representation of Infraspecific classification}

\section{Cucumis melo $\mathrm{L}$.}

Based on the length of ovary pubescence.

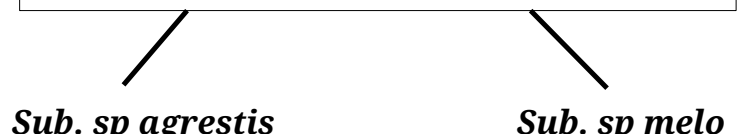

Sub. sp agrestis

Sub. sp melo

\begin{tabular}{|c|}
\hline $\begin{array}{c}\text { Spreading, usually long, } \\
\text { hairs } \\
\text { (Five varieties) }\end{array}$ \\
\hline
\end{tabular}

\section{1. momordica Roxb.}

2. acidulus Naudin

3. conomon Thunb

4. makuwa Makino

5. chinensis Pangalo

\section{Appresed, usually very short hairs (Twelve varieties)}

1. cantalupensis Naudin

2. reticulatus Ser

3. flexuosus L.

4. inodorus H.Jac

5. chandalak Gabaev

6. adana Pangalo

7. ameri Pangalo

8. chate Hasselq

9. chito Morren

10. dudaim $\mathrm{L}$.

11. tibish Mohamed

12. var. alwarensis A.

Pandey \& S.

Rajkumar var. nov. representation of infraspecific classification of melon is mentioned below.

An infraspecific classification on $C$. melo cited 18 groups belonging to 2 subspecies: subsp. melo and subs. agrestis (Naud.) Panglao. Subspecies agrestis includes ten var. momordica (Roxb.) Duthie et Fuller., acidulus Naud., var. chito (Morren) Naud., var. agrestis Naud., var. chate (Hasselq.) Sageret., var. conomon (Thunb.) Makino., var. dudaim (L.) Naud., var. texanus Naud., var. makuwa (Makino)., var. chinensis and eight varieties in subsp. melo consist of var. cantalupensis Naud., var. reticulatus Ser., var. flexuosus (L.) Naud., var. inodorus H.Jacq., var. chandalak Pangalo., var. adana Pangalo., var. ameri Pangalo. and var. tibish Mohamed (65) and which has been recently revised (66). A potential variety of cultivated vegetable melon was reported from the north-western parts of India, which is locally named Arya (Cucumis melo subsp. melo var. alwarensis A. Pandey \& S. Rajkumar) (67). Morphological and molecular characterization of the variety shows similarity with var. flexuosus (snake melon) in ovary pubescence and shelf life; hence it has been included in the subsp. melo.

Seed size can also consider an essential character to distinguish different subspecies of the melon. Varieties such as conomon and agrestis with seed lengths shorter than $9 \mathrm{~mm}$ were classified as subsp. agrestis, whereas large-seed type melon group catalupensis and flexuosus with seed length more than $9 \mathrm{~mm}$ were classified as subsp. melo (41). Another study concluded that var. acidulus and var. makua belong to oriental melon because of their thin pericarp short duration, tiny seed and reduced shelf 
life (68). Works had been conducted morphometric analysis on the melon germplasm in the humid tropics of south India and revealed that the collected germplasm belongs to two groups, $C$. melo var. momordica and $C$. melo var. acidulous $(69,70)$. There were similar type of study in Kerala landraces of melon and their uses and concluded that considerable variability exists in the fruit characteristics of varieties. This study also pointed out that the landraces belong to two varieties, acidulus and momordica (71).

Understanding and identifying the inter and infraspecific forms of melon is an unsolved problem to the botanist worldwide. In order to tackle this problem, every minute characteristic of the varieties are equally important. Therefore, here is an attempt to share some of the common pomological characteristic features (fruit shape, flesh colour, rind colour and ripening behaviour) of different varieties of melon, with particular reference to its common name and the most common cultivated places are listed below.

\section{Snap melon}

Snap melon (Cucumis melo var. momordica (Roxb.) Duthie \& Fuller) is an indigenous crop to India, popularly known as "phut" or "phoont," which means to split (72) (Fig. 2). It is a locally grown dessert melon in Kerala, known as Pottuvellari, and is cultivated in Thrissur, Ernakulam and Malappuram districts. The large-scale cultivation of the variety is confined to Uttar Pradesh, Rajasthan, Haryana, Punjab and Bihar in India and prevalent in arid and semi-arid regions (73). This crop is cultivating as an intercrop with cotton, maize and sorghum in this region. China is considered the world-leading producer of snap melon.

Ripe fruits of snap melon consumed as dessert while immature fruits generally used as a vegetable.

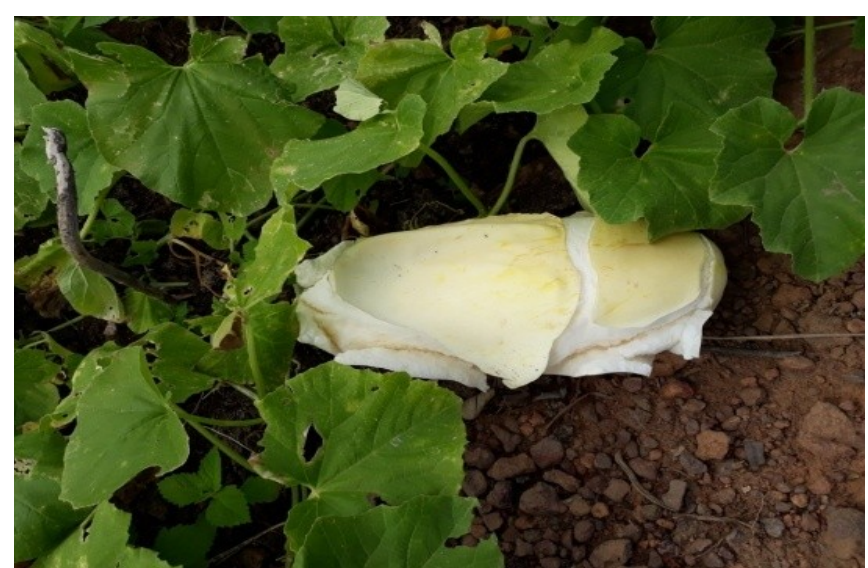

Fig. 2. Snap melon (Cucumis melo .var. Momordica Roxb.) Duthie \& Fuller).

In recent times, the juice of snap melon is gaining popularity as a refreshing drink due to its cooling effects (74). Hence, it could be used as a cleanser for the skin and first aid treatment for burns and abrasion. The fruit is stomachic and flowers are expectorant and emetic. Seed contain $12.5 \%$ to $39.1 \%$ oil. This edible and medicinal fruit is also a good summer drink since it reduces heat from the body.

\section{Culinary melon}

Culinary melon (Cucumis melo var. acidulus. L. Naudin), commonly known as sambar vellari, pickling melon, preserving melon etc., which is endemic to humid areas of tropical southern India and cultivated in Tamil Nadu, Kerala, Karnataka and Andhra Pradesh (Fig. 3). Brazil is the world-leading producer of culinary melon (75). Fruits are oval, smooth, orange in color, flesh white, firm crisp with no aroma and with long shelf life. The tender fruits are used for salad and sambar preparation.

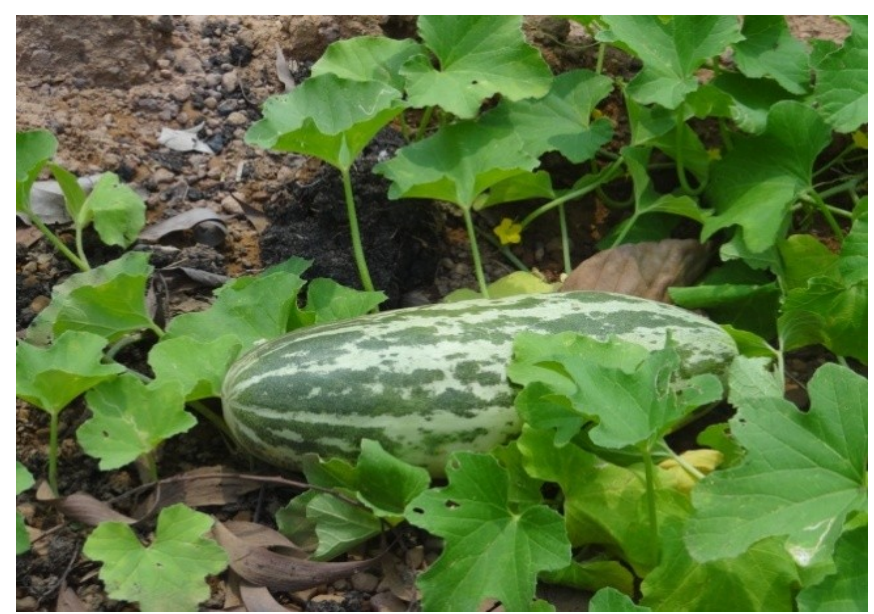

Fig. 3. Culinary melon (Cucumis melon. var. acidulus. L. Naudin).

\section{Oriental pickling melon}

Oriental pickling melon (C. melo var. conomon Thunb.) is the most primitive domesticated melon. Varieties such as conomon (pickling type), makuwa (dessert type) and chinensis are considered East Asian cultivated melon (19) (Fig. 4). Variety conomon and var. makuwa have been cultivated in Korea and South China (76). At the ripening stage, fruits of these varieties are smooth-skinned with sweet and fragrant pulp, but the unripe fruits are eaten as raw, cooked or pickled. Seed is used for the preparation of juice against dyspepsia. It was hypothesized that the origin of vars. makuwa and conomon is India and these varieties were introduced into China by the 'Silk Road' from the west (77-79). They also assumed that the origin of this melon is from wild melon (var. agrestis) in China (80).

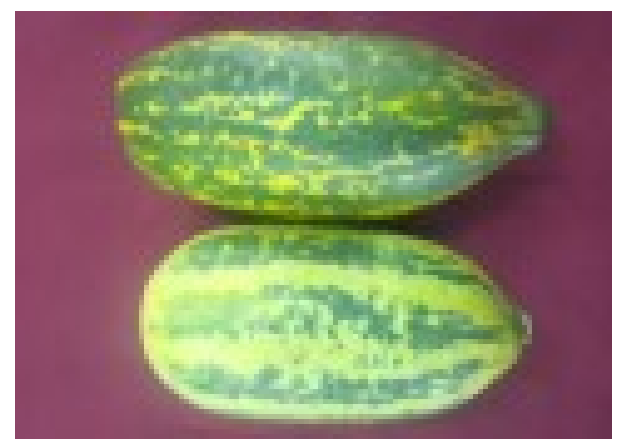

Fig. 4. Oriental pickling melon (C. melo var. conomon Thunb.).

\section{Chinese melon}

Chinese melon is divided into two types based on the thickness of the fruit skin. Thin-skinned melon is 
named Group conomon, thick-skinned as Hami melon ("Hami Gua" in Chinese) (Fig. 5). The landraces of Chinese melon are classified as var. chandalak Pang Greb (extra early Guardian melon), var. cassaba Pang Greb (round fruits with three or five carpels), var. ameri Pang Greb (summer melon) and var. zard Pang Greb (winter melon) (81). Among these varieties, zard and cassaba are categorized as var. inodorus (group Inodorus), whereas varieties were chandalak and ameri as independent varieties based on fruit shelf life (19).

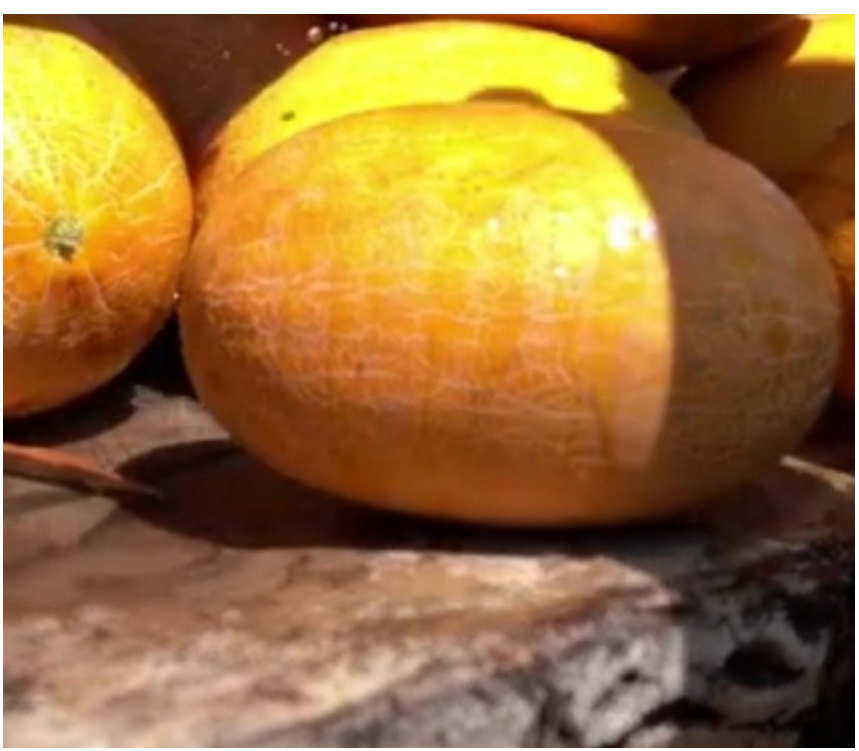

Fig. 5. Hami melon.

\section{Winter melon}

Winter melon (C. melo var. indorous H.Jac.) is a locally cultivating melon variety in the Island of Sicily in the Mediterranean Sea (Fig. 6). This variety includes honeydew melons, casaba and the Crenshaw melon. These varieties got significant importance in the economy of southern Italy. On the other hand, the fruits of Cucumis melo var. inodorus (honeydew melon) are non-climacteric types. Melon cultivation in Italy is an average of 21000 ha, of which about $40 \%$ is inodorus melon (82).

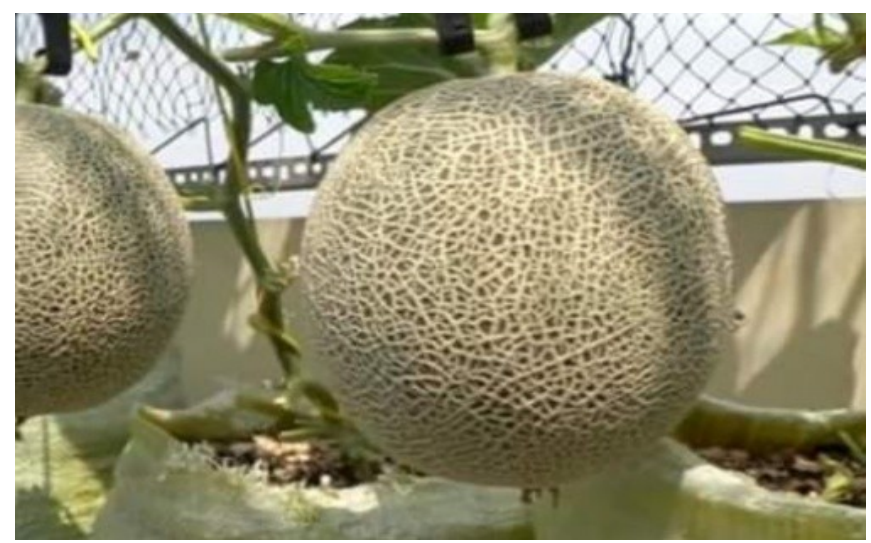

Fig. 6. Honeydew melon.

\section{Cantaloupe}

Cantaloupe (Cucumis. melo var. cantalupensis Naudin) is a lightly ribbed gray-green skinned fruit with sweet and flavorful flesh (82) (Fig. 7). Variety inodorus and var. cantalupensis are the most common growing melon varieties in the USA, Europe, Asia and Mediterranean countries. Charentais is a type of cantaloupe widely grown in Europe and the USA. Every year approximately 6400 ha of this region give the productivity of 60000-70000 tones of this crop (83). The fruits of this variety can be taken as either fruit salad or dessert.

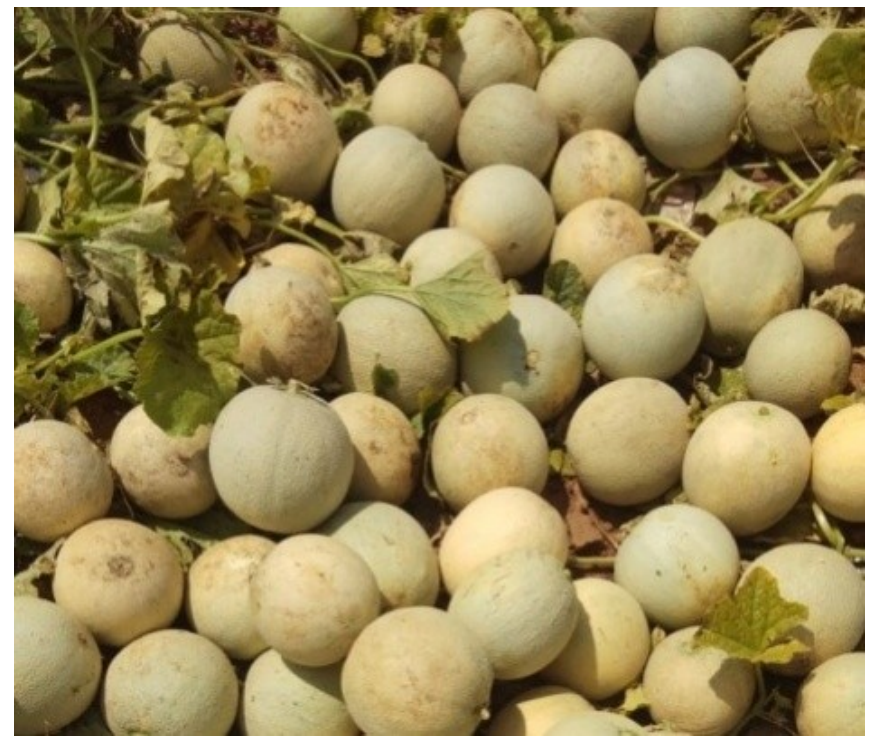

Fig. 7. Cantaloupe (Cucumis. melo var. cantalupensis Naudin).

\section{Musk melon}

Musk melon (Cucumis melo var. reticulatus Naud.) has fruit with a "net-like" (reticulated) peel (Fig. 8). It is a round melon with firm, moderately sweet flesh and orange in color. Fruit gorgeous Juicy flesh is mainly used for dessert preparation. Fruits of Cucumis melo var. cantalupensis Naud. and Cucumis melo var. reticulatus Naud. are a climacteric type with an aroma and quick softening nature. Nevertheless, nonclimacteric melons such as winter melon, oriental pickling melon, etc., possess a low-level aroma, palegreen flesh and slow softening. Hence, these melon varieties are typically more durable than climacteric varieties (64).

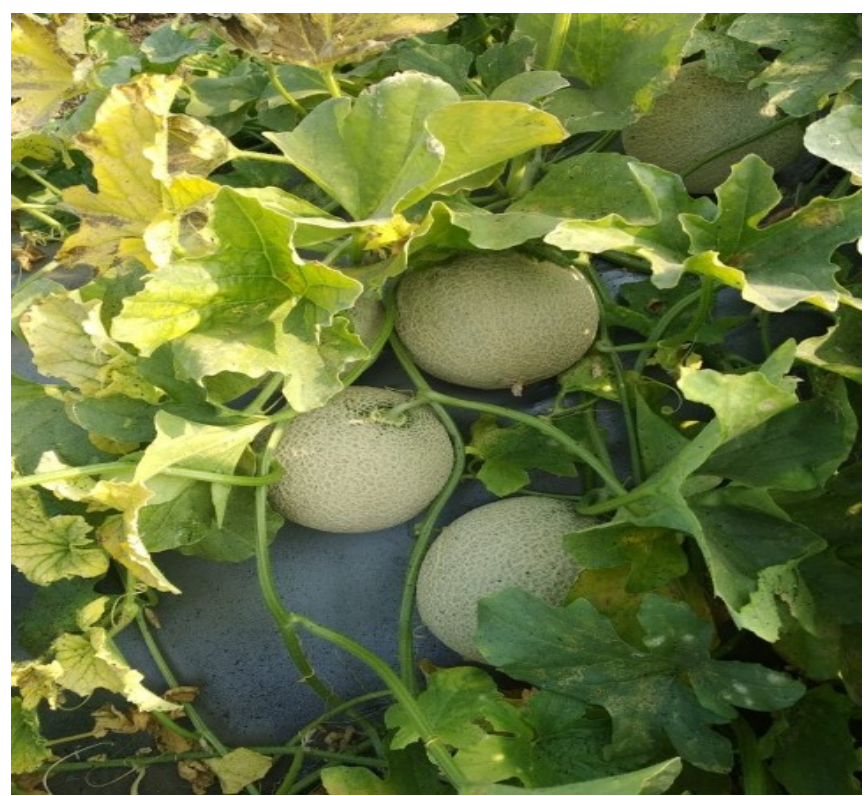

Fig. 8. Musk melon (Cucumis melo var. reticulatus Naud. 


\section{Snake melon}

Snake melon (Cucumis melo L. var. flexuosus (L.) Naud.) Or Armenian cucumber is considered one of the oldest horticultural crops in the world $(62,80)$ (Fig. 9). Landraces of var. flexuosus (known locally as "Fakous Baladi," in Arabic) have got the common name as "snake melon" because of their twisted, slender and bent fruits (19). It is a critical horticultural, rain-fed crop in the rural communities of Palestine and traditionally cultivated in the Mediterranean area. Fruits and flowers are edible. Fruits are used for salad preparation and stir fry (84).

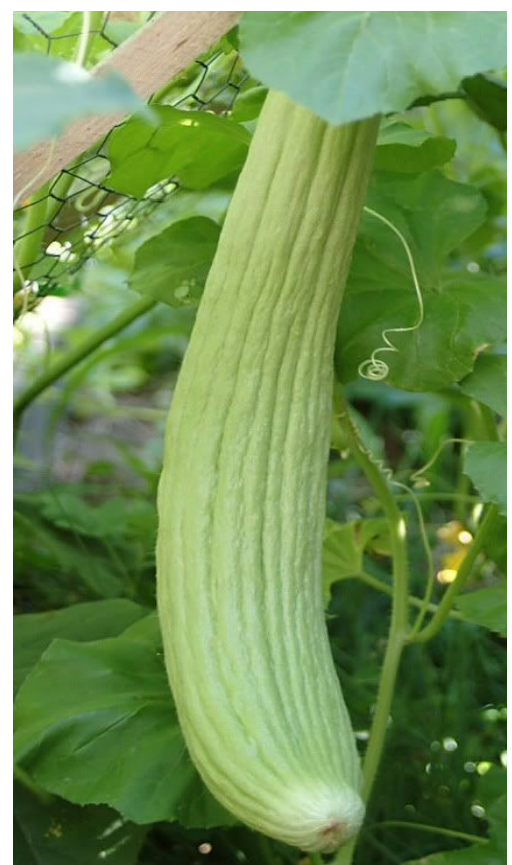

Fig. 9. Snake melon (Cucumis melo L. var. flexuosus (L.) Naud.).

\section{Arya}

Arya (Cucumis melo subsp. melo var. alwarensis A. Pandey et S. Rajkumar var. nov.) is a locally cultivating vegetable melon from the Alwar districts Rajasthan. Its large sub-globose, cylindrical fruits are rich in vitamin $\mathrm{C}$ and are used in salad, sambar and dessert. Mature fruits have smooth pericarp and long shelf life like snake melon, but the aroma of the fruits is like snap melon or the typical musk melon (67).

\section{Pocket melon}

Pocket melon (Cucumis melo var. dudaim (L.) Naudin), commonly known as 'Queen Anne's pocket melon' or 'fragrant melon.' Fruits of this variety are around or slightly oval shape with velvety skin and small reddish-yellow ochre stripes (65). The unique exotic musky fragrant of the fruits is generally considered a mix of pineapple, cantaloupe and a hint of jasmine. The velvety rind of this melon is lovely and its pulp is whitish, loose and edible. These are widely cultivated from the Caucasus to Afghanistan and Turkey for aromatic or ornamental purposes. Due to its lovely musky smell, these melons were carried in the pockets of Queen Anne in the Victorian period as a body fragrance. Hence, the name 'Queen Anne's pocket melon (85).

\section{Cucumber melon}

Cucumber melon (Cucumis melo L. var. chate (Hasselq.) Filov) is a traditionally cultivating melon in the area of Salento (Apulia region) of south Italy. This crop is locally called 'meloncella,' and its taxonomic position is $C$. melo ssp. melo convar. adzhur Greb. ex Mansf. \& Greb. var. chate. There are two varieties of 'Meloncella'; one has pale-skinned fruits and the other is dark green. Fruits are oblong, tender, crispy and covered with soft hairs. Its flavor is fresh and delicate than cucumbers ( $C$. sativus). One plant may produce more than 30 fruits, and each fruit weighs about 200$300 \mathrm{~g}$. The unripe fruits are eaten raw, like salad, with the first dishes. They have low sodium content and soluble solids. Therefore, it is easily digestible and suitable for a hypo caloric and hypoglycemic diet (86).

\section{Mango melon}

Mango melon (Cucumis melo var. chito (Morren) Naud.), commonly called mango melon or peach melon (Fig. 10). It is a drought-tolerant annual crop. The color, flavor and texture of the fruits are similar to mango or peach. Hence, the common name (88). This variety is widely distributed in Central America and the Caribbean Islands. According to Naudin, the chito group represents feral melons that are not cultivated (18). Round small and yellow fruits of this variety are used for dessert preparation and the seeds are tiny with a gelatinous sheath.

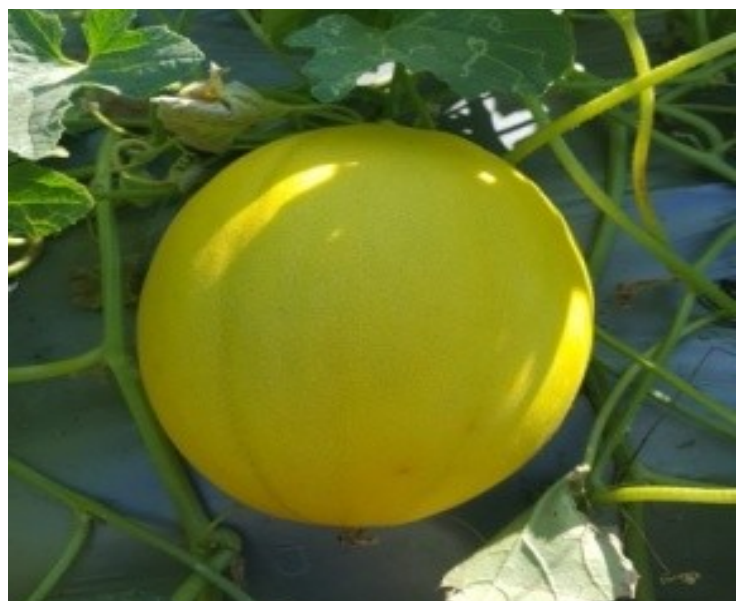

Fig. 10. Mango melon (Cucumis melo var. chito (Morren) Naud.).

\section{Seinat}

Seinat (Cucumis melo var. tibish Mohamed) is a locally grown melon variety in Sudan. This crop is unknown to its neighboring countries and is cultivated for its edible seeds. Seeds of this variety are a rich source of protein and essential amino acids. Hence, it is used as a fortifier in a variety of food items (88). The native people of Sudan eat roasted seeds as time pass (89).

\section{Conclusion}

Melon is a worldwide growing profitable crop. Much about melon fruit biology and crop cultivation is known. However, these fruits exhibit considerable variability in their shape, skin characters, flesh color, flesh thickness, sweetness, seed cavity, size etc. Hence, it is a significant hurdle for botanists to classify them 
at the subspecies level and provide an appropriate systematic position by analyzing their morphological and molecular characteristics. Diversity studies are inevitable to estimate and establish genetic correlation and better parental combinations for crop improvement programmes. The analysis of different melon diversity studies conducted worldwide suggests that fruits of var. acidulus and var. conomon could store for 8-9 months without losing their freshness. This long storage trait of the fruits could be exploited better in modern cultivars with low shelf life. The evaluation of snap melon germplasm from various parts of India shows that most of the accessions have high fruit acidity and pest resistance genes to combat different types of pests and diseases. These traits could also breed uniquely flavored melon cultivars and strengthen crop disease resistance against different pests and pathogens.

\section{Future Prospect}

Continuous and progressive research in melon diversity studies reveals that morphological and molecular characterization is inevitable to distinguish the varieties within the species or cultivars within the varieties. Molecular markers such as SSR and SNP are more suggestible in melon diversity studies because these techniques reveal the significant number of polymorphisms within genes of unknown varieties, leading to paternal analysis and cultivar identification. Since almost all melon varieties produce edible fruits, the development of elite varieties with better fruit qualities through molecular breeding or transgenic technology can only meet the global demand shortly.

\section{Acknowledgements}

The authors are grateful to the University of Kerala for providing fellowship to carry out the research and the Head, Department of Botany, University of Kerala for the help throughout the study. We are also acknowledging The Director, Centre for GeoInformation Science and Technology, University of Kerala to provide valuable support for the preparation of world distribution of melon varieties.

\section{Authors' contributions}

LM reviewed the literature, collected and compiled the data, drafted the manuscript. SB edited the manuscript and finalized it.

\section{Compliance with ethical standards}

Conflict of interest: The authors do not have any conflict of interest to declare.

Ethical issues: None.

\section{References}

1. FAOSTAT [Internet]. Canada: Food and Agriculture Organization of the United Nations. [cited 2017 Jan]. Available from: https://www.fao.org/faostat/en/
2. Malik AA, Vashisht VK, Singh K, Sharma A, Singh DK, Singh H, Monforte AJ, McCreight JD, Dhillon NP. Diversity among melon (Cucumis melo L.) landraces from the Indo-Gangetic plains of India and their genetic relationship with USA melon cultivars. Genetic resources and crop evolution. 2014 Aug; 61(6):1189-208. https://doi.org/10.1007/s10722-014-0101-x

3. International Congress on Biosystems Engineering. [Internet]. Available from http://icoben2019.mku.edu.tr

4. Sebastian P, Schaefer H, Telford IR, Renner SS. Cucumber (Cucumis sativus) and melon ( $C$. melo) have numerous wild relatives in Asia and Australia and the sister species of melon is from Australia. In: Proceedings of the National Academy of Sciences. 2010 Aug 10;107(32):14269-73. https://doi.org/10.1073/pnas.1005338107

5. Chen JF, Zhou XH. Cucumis. In: Wild Crop Relatives: Genomic and Breeding Resources 2011 (pp. 67-90). Springer, Berlin, Heidelberg. https://doi.org/10.1007/978-3-642-20450-0_6

6. Pitrat M. Phenotypic diversity in wild and cultivated melons (Cucumis melo). Plant Biotechnology. 2013:13-0813. https://doi.org/10.5511/plantbiotechnology.13.0813a

7. Taylor and Francis Online: Peer-reviewed journals [Internet]. Available from: http//www.tandfonline.com

8. Schieberle P, Ofner S, Grosch W. Evaluation of potent odorants in cucumbers (Cucumis sativus) and muskmelons (Cucumis melo) by aroma extract dilution analysis. Journal of Food Science. 1990 Jan; 55(1):193-95. https://doi.org/10.1111/j.13652621.1990.tb06050.x

9. Parente A, Buttaro D, Conversa G, Serio F, Santamaria P. Comparison between carousel cultivation systems and greenhouse barter systems I. Production aspects. 2005:19-27.

10. Singh D, Sharma. Genetic divergence among melon (Cucumis melo L.) groups for growth, yield and quality traits. M.Sc [dissertation]. Department of Vegetable Science and School of Agricultural Biotechnology, PAU, Ludhiana; 2006. Available from: http//www.file.scirp.org

11. Rolim PM, Seabra LM, de Macedo GR. Melon by-products: Biopotential in human health and food processing. Food Reviews International. $2020 \quad$ Jan 2;36(1):15-38. https://doi.org/10.1080/87559129.2019.1613662

12. Amaro AL, Oliveira A, Almeida DP. Biologically active compounds in melon: Modulation by preharvest, post-harvest and processing factors. In: Processing and Impact on Active Components in Food 2015 Jan 1 (pp. 165-71). Academic Press. https://doi.org/10.1016/B978-0-12-404699-3.00020-2

13. Lester G. Melon (Cucumis melo L.) fruit nutritional quality and health functionality. HortTechnology.1997Jul1;7(3):222-27. https://doi.org/10.21273/Hottech.7.3.222

14. Robinson RW, Decker-Walters DS. Cucurbits. New York: CAB International. 1997; 226.

15. Stepansky A, Kovalski I, Perl-Treves R. Intraspecific classification of melons (Cucumis melo L.) in view of their phenotypic and molecular variation. Plant Systematics and $\begin{array}{llll}\text { Evolution. } & 1999 & \text { Sep; } & \text { 217(3):313-32. }\end{array}$ https://doi.org/10.1007/BF00984373

16. Looking For A Professional Download PDF. United States (San Francisco, California). [Internet]. [cited June 2021]. Available from https:// www.mafiadoc.com

17. Miller P. The gardener's dictionary. 1835 p.200-10.

18. Naudin C. Essays on a monograph of species and varieties of the genus Cucumis. Ann Sci Nat. 1859;11:5-87.

19. Munger HM, Robinson RW. Nomenclature of Cucumis melo L. Cucurbit Genet Coop Rep. 1991 Jul;14:43-44.

20. Swamy KR. Origin, distribution and systematics of culinary cucumber (Cucumis melo subsp. agrestis var. conomon). Journal of Horticultural Sciences. 2017 Jun 30; 12(1):1-22.

21. Pitrat M, Hanelt P, Hammer K. Some comments on infraspecific classification of cultivars of melon. InVII Eucarpia Meeting on Cucurbit Genetics and Breeding 510 2000 Mar 19 (pp.29-36). https://doi.org/10.17660/ActaHortic.2000.510.4

22. Yashiro K, Iwata H, Akashi Y, Tomita KO, Kuzuya M, Tsumura Y, Kato K. Genetic relationship among East and South Asian melon 
(Cucumis melo L.) revealed by AFLP analysis. Breeding science. 2005;55(2):197-206. https://doi.org/10.1270/jsbbs.55.197

23. Ingrouille M, Eddie . Plants: Diversity and Evolution [Internet]. Available from:: http://epdf.pub

24. Li HL. The vegetables of ancient China. Economic Botany. 1969 Jul 1; 23(3):253-60. https://doi.org/10.1007/BF02860457

25. Watson W. Early domestication in China. The domestication and exploitation of plants and animals. 1969.

26. Stol M. The Cucurbitaceae in the cuneiform texts. Bull Syer Agric. 1987;3:81-92.

27. Manniche L. An ancient Egyptian herbal University of Texas Press Austin. TX. 1989;163:167.

28. Walters TW. Historical overview on domesticated plants in China with particular emphasis on the Cucurbitaceae. Economic Botany. $1989 \quad$ Jul; $43(3): 297-313$. https://doi.org/10.1007/BF02858729

29. Decker-Walters DS. Cucurbits, Sanskrit, and the Indo-Aryas 1. Economic $\quad$ Botany. $1999 \quad$ Jan;53(1):98-112. https://doi.org/10.1007/BF02860800

30. Chadha ML, Nandpuri KS. Hybrid vigour studies in muskmelon. Indian Journal of Horticulture. 1980;37(3):276-82.

31. Pitrat M. Melon. In: Vegetables I 2008 (pp. 283-315). Springer, New York, NY. https://doi.org/10.1007/978-0-387-30443-4_9

32. Pangalo KJ. Critical review of the main literature on the taxonomy, geography and origin of cultivated and partially wild melons. Trudy Prikl. Bot. 1929;23:397-442.

33. Frary A, Sigva HO, Tan A, Taskın T, Inal A, Mutlu S, Haytaoglu M, Doganlar S. Molecular genetic diversity in the Turkish national melon collection and selection of a preliminary core set. Journal of the American Society for Horticultural Science. 2013 Jan 1; 138(1):50-56. https://doi.org/10.21273/JASHS.138.1.50

34. Whitaker TW, Bemis WP, Cucurbits. In: N.W. Symmonds (Ed.) Evolution of Crop Plants, Longman, London and New York, 1976.64-69.

35. Kroon GH, Custers JB, Kho YO, Den Nijs AP, Varekamp HQ. Interspecific hybridization in Cucumis (L.). I. Need for genetic variation, biosystematic relations and possibilities to overcome cross ability barriers. Euphytica. 1979 Nov; 28(3):723-28. https://doi.org/10.1007/BF00038940

36. Ramachandran C, Narayan RK. Chromosomal DNA variation in Cucumis. Theoretical and applied genetics. 1985 Mar;69(5):497502.

https://doi.org/10.1007/BF00251092

37. Chen JF, Adelberg J. Interspecific hybridization in Cucumisprogress, problems, and perspectives. HortScience. 2000 Feb 1;35(1):11-15. https://doi.org/10.21273/HORTSCI.35.1.11

38. Mallick MF, Masui M. Origin, distribution and taxonomy of melons. Scientia Horticulturae. 1986 Apr 1; 28(3):251-61. https://doi.org/10.1016/0304-4238(86)90007-5

39. Dhillon NP, Ranjana R, Singh K, Eduardo I, Monforte AJ, Pitrat M, Dhillon NK, Singh PP. Diversity among landraces of Indian snap melon (Cucumis melo var. momordica). Genetic Resources and Crop Evolution. 2007 Sep; 54(6):1267-83. https://doi.org/10.1007/s10722-006-9108-2

40. Kirkbride JH. Biosystematic monograph of the genus Cucumis (Cucurbitaceae): botanical identification of cucumbers and melons. Parkway Publishers, Inc.; 1993.

41. Akashi Y, Fukuda N, Wako T, Masuda M, Kato K. Genetic variation and phylogenetic relationships in East and South Asian melons, Cucumis melo L., based on the analysis of fiveisozymes. Euphytica. $2002 \quad$ Jun;125(3):385-96. https://doi.org/10.1023/A:1016086206423

42. Dane FE. Cytogenetics of the genus Cucumis. Chromosome engineering in plants: Genetics, Breeding, Evolution. 1991; 1 : 201-14. https://doi.org/10.1016/B978-0-444-88260-8.50016-1

43. Lopez-Sese AI, Staub JE, Gomez-Guillamon ML. Genetic analysis of Spanish melon (Cucumis melo L.) germplasm using a standardized molecular-marker array and geographically diverse reference accessions. Theoretical and Applied Genetics.
2003 Dec 1; 108(1):41-52. https://doi.org/10.1007/s00122-0031404-Z

44. Neuhausen SL. Evaluation of restriction fragment length polymorphism in Cucumis melo. Theoretical and Applied Genetics. $1992 \quad$ Jan; 83(3):379-84 https://doi.org/10.1007/BF00224286

45. Staub JE, Danin-Poleg Y, Fazio G, Horejsi T, Reis N, Katzir N. Comparative analysis of cultivated melon groups (Cucumis melo L.) using random amplified polymorphic DNA and simple sequence repeat markers. Euphytica. 2000 Oct; 115(3):225-41. https://doi.org/10.1023/A:1004054014174

46. Luan F, Delannay I, Staub JE. Chinese melon (Cucumis melo L.) diversity analyses provide strategies for germplasm curation, genetic improvement and evidentiary support of domestication patterns. Euphytica. 2008 Nov; 164(2):445-61. https://doi.org/10.1007/s10681-008-9699-0

47. Nakata E, Staub JE, Lopez-Sese AI, Katzir N. Genetic diversity of Japanese melon cultivars (Cucumis melo L.) as assessed by random amplified polymorphic DNA and simple sequence repeat markers. Genetic Resources and Crop Evolution. 2005 Jun;52(4):405-19.

https://doi.org/10.1007/s10722-005-2258-9

48. Soltani F, Akashi Y, Kashi A, Zamani Z, Mostofi Y, Kato K. Characterization of Iranian melon landraces of Cucumis melo L. Groups Flexuosus and Dudaim by analysis of morphological characters and random amplified polymorphic DNA. Breeding Science. 2010;60(1):34-45. https://doi.org/10.1270/jsbbs.60.34

49. Tanaka K, Nishitani A, Akashi Y, Sakata Y, Nishida H, Yoshino H, Kato K. Molecular characterization of South and East Asian melon, Cucumis melo L., and the origin of Group Conomon var. makuwa and var. conomon revealed by RAPD analysis. Euphytica. $2007 \quad$ Jan;153(1):233-47. https://doi.org/10.1007/s10681-006-9259-4

50. Garcia-Mas J, Monforte AJ, Arus P. Phylogenetic relationships among Cucumis species based on the ribosomal internal transcribed spacer sequence and microsatellite markers. Plant Systematics and Evolution. 2004 Sep; 248(1):191-203. https://doi.org/10.1007/s00606-004-0170-y

51. Monforte AJ, Garcia-Mas J, Arus P. Genetic variability in melon based on microsatellite variation. Plant Breeding. 2003 Apr;122(2):153-7. $\quad$ https://doi.org/10.1046/j.14390523.2003.00848.x

52. Garcia-Mas J, Oliver M, Gomez-Paniagua H, De Vicente MC. Comparing AFLP, RAPD and RFLP markers for measuring genetic diversity in melon. Theoretical and Applied Genetics.20000ct1;101(5-6):860-64. https://doi.org/10.1007/s001220051553

53. Yashiro K, Iwata H, Akashi Y, Tomita KO, Kuzuya M, Tsumura Y, Kato K. Genetic relationship among East and South Asian melon (Cucumis melo L.) revealed by AFLP analysis. Breedingscience.2005;55(2):197-206. https://doi.org/10.1270/jsbbs.55.197

54. Jung J, Park G, Oh J, Jung JK, Shim EJ, Chung SM, Lee GP, Park Y. Assessment of the current infraspecific classification scheme in melon (Cucumis melo L.) based on genome-wide single nucleotide polymorphisms. Horticulture, Environment and Biotechnology.2020Jun;61(3):537-47. https://doi.org/10.1007/s13580-020-00230-0

55. Kishor DS, Song WH, Noh Y, Lee GP, Park Y, Jung JK, Shim EJ, Chung SM. Development of SNP markers and validation assays in commercial Korean melon cultivars, using Genotyping-bysequencing and Fluidigm analyses. Scientia Horticulturae. 2020 Mar 15; 263: 109113. https://doi.org/10.1016/j.scienta.2019.109113

56. Jeffrey C. A review of the Cucurbitaceae. Botanical Journal of the Linnean Society. 1980 Oct 1;81(3):233-47. https://doi.org/10.1111/j.1095-8339.1980.tb01676.x

57. Jeffrey C. Cucurbitaceae. In: Hanelt P, Institute of Plant Genetics and Crop Plant Research (eds) Mansfield's Encyclopedia of agricultural and horticultural crops. 2001; vol 3. SpringerVerlag, Berlin, pp. 1510-57.

58. Poland JA, Rife TW. Genotyping-by-sequencing for plant breeding and genetics. Plant Genome 2012;5:92-102. https://doi.org/10.3835/plantgenome2012.05.0005 
59. Sabato D, Esteras C, Grillo O, Peña-Chocarro L, Leida C, Ucchesu M, Usai A, Bacchetta G, Picó B. Molecular and morphological characterisation of the oldest Cucumis melo L. seeds found in the Western Mediterranean Basin. Archaeological and Anthropological Sciences. 2019 Mar;11(3):789-810. https://doi.org/10.1007/s12520-017-0560-Z

60. Burger Y, Paris HS, Cohen R, Katzir N, Tadmor Y, Lewinsohn E, Schaffer AA. 3 Genetic Diversity of Cucumis melo. Horticultural $\begin{array}{llll}\text { reviews. } 2010 \quad \text { Jan } & \text { 36(1). }\end{array}$ https://doi.org/10.1002/9780470527238.ch3

61. Brickell CD, Baum BR, Hetterscheid WL, Leslie AC, McNeill J, Trehane P, Vrugtman F, Wiersema JH. International Code of Nomenclature for Cultivated Plants (ICNCP or Cultivated Plant Code) incorporating the Rules and Recommendations for naming plants in cultivation. ed. 7. Adopted by the International Union of Biological Sciences Commission for the Nomenclature of Cultivated Plants. Acta Horticulturae. 2004. https://doi.org/10.17660/ActaHortic.2004.647.5

62. Blanca J, Esteras C, Ziarsolo P, Perez D, Collado C, de Pablos RR, Ballester A, Roig C, Canizares J, Pico B. Transcriptome sequencing for SNP discovery across Cucumis melo. BMC genomics. 2012 Dec; 13 (1):1-8. https://doi.org/10.1186/1471-216413-280

63. Esteras C, Formisano G, Roig C, Díaz A, Blanca J, Garcia-Mas J, Gomez- Guillamon ML, Lopez-Sese AI, Lazaro A, Monforte AJ, Pico B. SNP genotyping in melons: genetic variation, population structure and linkage disequilibrium. Theoretical and Applied Genetics. $2013 \quad$ May 1; 126(5):1285-303. https://doi.org/10.1007/s00122-013-2053-5

64. Pitrat M. Phenotypic diversity in wild and cultivated melons (Cucumis melo). Plant Biotechnology. 2013:13-0813. https://doi.org/10.5511/plantbiotechnology.13.0813a

65. Hammer K, Gladis T. Notes on infraspecific nomenclature and classifications of cultivated plants in Compositae, Cruciferae, Cucurbitaceae, Gramineae (with a remark on Triticum dicoccon Schrank) and Leguminosae. Genetic resources and crop evolution. $2014 \quad$ Dec; 61(8):1455-67. https://doi.org/10.1007/s10722-014-0148-8

66. Pitrat M. Melon genetic resources: phenotypic diversity and horticultural taxonomy. In Genetics and genomics of Cucurbitaceae 2016 (pp. 25-60). Springer, Cham. https://doi.org/10.1007/7397_2016_10

67. Pandey A, Rajkumar S. A new potential variety of cultivated melon (Cucumis melo L.) from north western India. Genetic Resources and Crop Evolution. 2021 Feb;68(2):785-94. https://doi.org/10.1007/s10722-020-00997-2

68. Liu L, Kakihara F, Kato M. Characterization of six varieties of Cucumis melo L. based on morphological and physiological characters, including shelf-life of fruit. Euphytica. 2004 Mar;135 (3):305-13. https://doi.org/10.1023/B:EUPH.0000013330.66819.6f

69. Manohar SH, Murthy HN. Estimation of phenotypic divergence in a collection of Cucumis melo, including shelf-life of fruit. Scientia horticulturae. $2012 \quad$ Dec 4;148:74-82. https://doi.org/10.1016/j.scienta.2012.09.025

70. Fergany M, Kaur B, Monforte AJ, Pitrat M, Rys C, Lecoq H, Dhillon NP, Dhaliwal SS. Variation in melon (Cucumis melo) landraces adapted to the humid tropics of southern India. Genetic Resources and Crop Evolution. 2011 Feb;58(2):225-43. https://doi.org/10.1007/s10722-010-9564-6

71. Koli SP, Murthy HN. Estimation of phenotypic divergence in a collection of Cucumis melo from Kerala State, Southern India.

72. Dhillon NPS, Singh J, Fergany M, Monforte AJ, Sureja AK. Phenotypic and molecular diversity among landraces of snap melon (Cucumis melo var. momordica) adapted to the hot and humid tropics of eastern India. Plant Genetic Resources. 2009; 7, 3: 291-300. https://doi.org/10.1017/S1479262109990050

73. Hazara P, Chattopadhyay A, Karmakar K, Dutta S. Modern technology in vegetable production. New India Pub. Agency; 2011.

74. Pareek OP, Samadia DK. Promising indigenous cucurbit varieties. 2002.
75. FAOSTAT (2007) Food and agriculture Organization of the United Nations. http://faostat.fao.org Accessed Jan 2018.

76. Kitamura S. Notes on Cucumis of far East. Acta Phytotaxonomica et Geobotanica. 1950 Feb 28; 14(2):41-44.

77. Robinson RW, Decker-Walters DS. Cucurbits. Cab international; 1997.

78. Kitamura S. The origin of the cultivated plants of China. Acta Phytotaxonomica et Geobotanica. 1951 Jul 30; 14(3):81-5.

79. Kato K, Akashi Y, Tanaka K, Wako T, Masuda M. Genetic characterization of east and south Asian melons, Cucumis melo, by the analysis of molecular polymorphisms and morphological characters. In II International Symposium on Cucurbits 588 2001 Sep 28 (pp. https://doi.org/10.17660/ActaHortic.2002.588.33

80. Walters TW, Thieret JW. Notes on economic plants. Economic Botany. $1993 \quad$ Jan; 47(1):99-100. https://doi.org/10.1007/BF02862210

81. Lin DP. Classification of melon. Chinese Melon. Popular Science Press, Beijing (In Chinese). 1991:9-21.

82. Verzera A, Dima G, Tripodi G, Condurso C, Crino P, Romano D, Mazzaglia A, Lanza CM, Restuccia C, Paratore A. Aroma and sensory quality of honeydew melon fruits (Cucumis melo L. subsp. melo var. inodorus H. Jacq.) in relation to different rootstocks. Scientia Horticulturae. 2014 Apr 16; 169:118-24. https://doi.org/10.1016/j.scienta.2014.02.008

83. McCreight JD, H Nerson, R Grumet, Melon, Cucumis melo L. In: G. Kallos \& B.O. Bergh (Eds.), Genetic Improvement of Vegetable Crops, Pergamon Press, New York, $1993 . \quad 267-294$ https://doi.org/10.1016/B978-0-08-040826-2.50024-2

84. Ali-Shtayeh MS, Jamous RM, Shtaya MJ, Mallah OB, Eid IS, Zaitoun SY. Morphological characterization of snake melon (Cucumis melo var. flexuosus) populations from Palestine. Genetic Resources and Crop Evolution. 2017 Jan 1; 64(1):7-22. https://doi.org/10.1007/s10722-015-0329-0

85. Aubert C, Pitrat M. Volatile compounds in the skin and pulp of Queen Anne's pocket melon. Journal of Agricultural and Food Chemistry. $2006 \quad$ Oct 18; 54(21):8177-82. https://doi.org/10.1021/jf061415s

86. Laghetti G, Accogli R, Hammer K. Different cucumber melon (Cucumis melo L.) races cultivated in Salento (Italy). Genetic Resources and Crop Evolution. 2008 Jun; 55(4):619-23. https://doi.org/10.1007/s10722-008-9341-y

87. Terroir Seeds LLC P O Box 4995 Chino Valley AZ 86323. [Internet]. Available from: www.store.underwoodgardens.com

88. Siddeeg A, Xu Y, Jiang Q, Xia W. Physicochemical and functional properties of flour and protein isolates extracted from seinat (Cucumis melo var. tibish) seeds. Food Science and $\begin{array}{llll}\text { Biotechnology. } & 2014 & \text { Apr } & 1 ; 23(2): 345-53\end{array}$ https://doi.org/10.1007/s10068-014-0048-x

89. Azhari S, Xu YS, Jiang QX, Xia WS. Physicochemical properties and chemical composition of Seinat (Cucumis melo var. tibish) seed oil and its antioxidant activity. Grasas y aceites. 2014 Jan 1; 65(1). https://doi.org/10.3989/gya.074913

\section{Additional information}

Peer review information: Plant Science Today thanks Sectional Editor and the other anonymous reviewers for their contribution to the peer review of this work.

Reprints and permissions information is available at https://horizonepublishing.com/journals/index.php/PST/open_access_policy

Publisher's Note: Horizon e-Publishing Group remains neutral with regard to jurisdictional claims in published maps and institutional affiliations.

To cite this article: Lija M, Beevy S S A review on the diversity of Melon. Plant Science Today. 2021;8(4):995-1003. https://doi.org/10.14719/pst.1300

Plant Science Today, published by Horizon e-Publishing Group, is covered by Scopus, Web of Science, BIOSIS Previews, Clarivate Analytics, etc. See https://horizonepublishing.com/journals/index.php/PST/indexing_abstracting 